\title{
Optimization of Overmolding Process of Metal-Plastic Part
}

Ernest Gondár, Alexander Schrek, Pavol Švec

Faculty of Mechanical Engineering, Slovak University of Technology in Bratislava. Pionierska 15, 83102 Bratislava. Slovak Republic. E-mail: ernest.gondar@stuba.sk, alexander.schrek@stuba.sk, pavol.svec@stuba.sk

Metal-plastic parts with steel inserts prepared by overmolding technique showed several cracks. Cracks marked as no 1 and 2 were noticed immediately after overmoulding process. Cracks no 3 and 4 were propagated only several days after overmolding, during post crystallization of plastic. The superposition of both high residual stresses at the metal-plastic interface and creation of cold joints in overmolding plastic were the reasons of cracks initiations. Residual stresses at the metal-plastic interface exceeding the yield strength of plastic were confirmed by simulation in Moldflow software. The differences in the melt front temperature above $20^{\circ} \mathrm{C}$ were simulated in the critical areas where the cold joints created in the real metal-plastic parts. Cracks no 1, 2 and 3 were eliminated by increasing of plastic thickness in the critical areas. Cracks no 4 were eliminated by decreasing of packing pressure, what also contributed to the elimination of cracks no 3.

Keywords: metal-plastic part, overmolding, crack, cold joint, residual stress

\section{Acknowledgements}

This article was created with the support of the Ministry of Education, Science, Research and Sport of the Slovak Republic within the Research and Development Operational Programme for the project "University Science Park of STU Bratislava", ITMS 26240220084, co-funded by the European Regional Development Fund.

\section{References}

[1] LUCCHETTA, G., MARINELLO, F., BARIANI, P.F. (2011). Aluminium sheet surface roughness correlation with adhesion in polymer metal hybrid overmolding. CIRP Annals - Manufacturing Technology, vol. 60, Elsevier, Amsterdam, pp. $559-562$.

[2] SCREIER-ALT, T., REHME, F., ANSORGE, F., REICHL, H. (2011). Simulation and experimental analysis of large area substrate overmolding with epoxy molding compounds. Microelectronics Reliability, vol. 51, Elsevier, Amsterdam, pp. $668-675$.

[3] ROSSA-SIERA, A., SÁNCHES-SOTO, M., ILLESCAS, S., MASPOCH, M.LI. (2009). Study of the interface behaviour between MABS/TPU bi-layer structures obtained through over molding. Materials and Design, vol. 30, Elsevier, Amsterdam, pp. 3979 - 3988.

[4] DULEBA, B., GREŠKOVIČ, F. (2012). Application of CA systems at design and simulation of plastic molded parts. International Journal of Advanced Engineering Technology, vol. 3, no. 4, technicaljournalsonline.com, Durg, India, pp. 1-7.

[5] CHUN, H.D. (1999). Cavity filling analyses of injection molding simulation: bubble and weld line formation. Journal of Materilas Processing Technology, vol. 89 - 90, Elsevier, Amsterdam, pp. 177 - 181.

[6] DULEBA, B., GREŠKOVIČ, F. (2012). Moldflow simulations of plastic molded part. It-strojár. vol. 4, no. 1, TU SjF Košice, Košice pp. $1-8$

[7] GRUjiciC, V., SEllapPAN, V., PANDURAGAN, B., Li, G., VAHIDI, A., SEYR, N., ERDMANN, M., HOLZLEITNER, J. (2008). Computational analysis of injection-molding residual-stress development in direct adhesion polymer-to-metal hybrid body-in-white components. Journal of Materilas Processing Technology, vol. 203, no. 1 - 3, Elsevier, Amsterdam, pp. 19 - 36.

[8] SUBA, O, SYKOROVA, L., LUKOVICS, I. (2012) Stress Analysis of Injection - moulded Cylindrical Parts Reinforced with Short Fibres. Manufacturing Technology, vol. 12, no. 13, J. E. Purkyne University in Usti nad Labem, Usti nad Labem pp. 254 - 259

[9] GREŠKOVIČ, F., DULEBOVÁ, L. (2009). Simulation utilization in designing process of injection moulds according to quality. In: Bezpečnost'-Kvalita - Spol'ahlivost'. CD ROM, TU SjF Košice, Košice, pp. 81-84

[10]GRUJICIC, V., SEllapPAN, V., KOTRIKA, S., ARAKERE, G., OBIEGLO, A., ERDMANN, M., HOLZLEITNER, J. (2009). Suitability analysis of a polymer-metal hybrid technology based on high-strength steels and direct polymer-to-metal adhesionfor use in load-bearing automotive body-in-white applications. Journal of Materilas Processing Technology, vol. 209, no. 7, Elsevier, Amsterdam, pp. 1877 - 1890 